\title{
PENERAPAN ARCS PADA PEMBELAJARAN MATEMATIKA MENGGUNAKAN MODEL STAD DAN NHT DI SMP NEGERI 3 AMPELGADING MALANG
}

\author{
Ummi Laila Nurjannah \\ University of Muhammadiyah Malang \\ ummilailanurjannah@yahoo.com
}

\begin{abstract}
The purpose of the study was to describe: the application of the ARCS model of learning mathematics using STAD and NHT in SMP Negeri 3 Malang Ampelgading, activities of teachers and learning activities of students during the learning process, as well as student learning outcomes and student motivation. The approach taken in this study is a qualitative and quantitative approach. The experiment was conducted in the first semester of 2013-2014 academic year on 28 October to 16 November 2013 in which the application of the ARCS model of learning using STAD and NHT to see the activities of the teacher and student learning activities as processes of learning, student learning outcomes are seen from individual tasks and daily test as well as the student's motivation to learn the subject while in the eighth grade students of SMP Negeri 3 Malang Ampelgading as objects. Instrument used is the observation sheet to see the activities of teachers and students' learning activities, individual assignments and daily test to look at student learning outcomes and questionnaire to see the students' motivation . The results showed that: 1) the application of the ARCS model of learning mathematics using STAD and NHT in SMP Negeri 3 Malang Ampelgading accomplished in accordance with the RPP planned despite having some problems at the beginning of the meeting, 2) the activities of teachers and students' learning activities always have improvement in every meeting, in which the first meeting activities better teacher in class VIII-A, the second meeting better in class VIII-B and the third meeting has the same score, while for student activities, class VIII-B is always more better than VIII-A, 3) there is no difference in learning outcomes between students of class VIII-A that is taught using STAD and the ARCS model of class VIII-B are taught using a model $A R C S$ and $N H T, 4)$ there is no difference between the learning motivation of class VIII-A students who are taught using STAD and the ARCS model of class VIII-B are taught using a model ARCS and $N H T$.
\end{abstract}

Kata Kunci: ARCS (Attention, Relevance, Confidence, Satisfaction), STAD (Student Teams Achievement Divisions), NHT (Numbered Heads Together), Aktifitas Belajar, Hasil Belajar, Motivasi Belajar.

\section{PENDAHULUAN}

Pembelajaran adalah proses yang diselenggarakan oleh guru untuk membelajarkan siswa dalam belajar bagaimana belajar memperoleh dan memproses pengetahuan, keterampilan dan sikap (Dimyati \& Mudjiono, 2009: 10). Pembelajaran yang ideal adalah pembelajaran yang mampu menarik minat siswa untuk belajar, memacu keaktifan siswa ketika pembelajaran berlangsung, mampu memotivasi siswa untuk belajar hingga memahami materi dan mengerjakan sendiri soal latihan hingga mendapat nilai yang memuaskan. Pembelajaran yang ideal tergantung dari peranan guru, siswa, serta pengelolaan kelas yang baik serta menarik. 
Peranan guru dalam pembelajaran yaitu menyelenggarakan kegiatan belajar mengajar, bertindak mengajar serta mengevaluasi hasil belajar. Sedangkan peranan siswa dalam pembelajaran adalah belajar, yaitu mengalami proses belajar yang bisa membuat kemampuan mental siswa semakin meningkat serta mencapai hasil belajar. Pengelolaan kelas yang baik serta menarik akan berpengaruh terhadap proses dan hasil pembelajaran. Jika suasana kelas menyenangkan, siswa akan terpacu untuk aktif dalam pembelajaran, serta termotivasi untuk memahami pelajaran sehingga hasil belajar siswa menjadi baik dan memuaskan.

Dari hasil observasi pada kelas VIII-A di SMP Negeri 3 Ampelgading Malang pada hari Selasa, 21 Mei 2013 dapat dilihat aktifitas siswa dan guru dalam pembelajaran. Guru menjelaskan materi menggunakan metode ceramah dan tanya jawab. Di mana dalam metode ini guru menjelaskan materi di depan kelas secara keseluruhan, siswa diizinkan untuk bertanya apabila ada materi yang belum dipahami. Aktifitas siswa dalam pembelajaran tersebut tergolong pasif, karena kurang adanya interaksi antara siswa dan guru maupun siswa dan siswa, bahkan beberapa siswa terlihat tidak mendengarkan dan tidur. Dalam kegiatan tanya jawab, hanya beberapa siswa yang mengajukan pertanyaan. Kemungkinan yang ada adalah: 1) siswa sudah paham sehingga hanya beberapa yang belum paham yang bertanya; 2) siswa belum paham dan tidak tahu apa yang ingin ditanyakan serta tidak berani untuk bertanya.

Motivasi siswa dalam pembelajaran bisa dibilang belum ada, hal ini terlihat ketika mengerjakan soal latihan secara individu. Hanya beberapa siswa yang mengerjakan sendiri, sebagian besar lebih memilih untuk tidak mengerjakan dan menyalin jawaban siswa lain jika telah selesai. Menyelesaikan tugas dari guru lebih dianggap penting daripada pemahaman dalam mengerjakan soal yang mengakibatkan hasil belajar siswa bervariasi ketika ulangan harian. Siswa yang sudah terbiasa mengerjakan soal latihan di LKS dengan kemampuannya sendiri mendapatkan nilai yang baik, sedangkan untuk siswa yang terbiasa menyontek mendapat nilai yang rendah.

Berdasarkan uraian tentang pembelajaran ideal dengan fakta yang terjadi dalam pembelajaran di SMA Taman Madya Malang, maka terdapat beberapa permasalahan diantaranya adalah : 1) model pembelajaran yang digunakan oleh guru cenderung monoton dan kurang dapat menarik perhatian siswa, guru menyampaikan materi secara 
tuntas tanpa memperhatikan pemahaman siswa, seharusnya dalam pembelajaranharus mengutamakan pemahaman siswa; 2) motivasi siswa dalam pembelajaran masih kurang, hal ini terlihat dari sedikitnya siswa yang memperhatikan penjelasan guru dalam kelas; 3) aktifitas belajar siswa kurang optimal, siswa cenderung bersikap pasif ketika pembelajaran berlangsung; 4) hasil belajar siswa rendah disebabkan karena siswa kurang dalam pemahaman materi yang mengakibatkan siswa mendapat nilai yang rendah.

Motivasi siswa dalam belajar harus diperhatikan karena memegang peranan yang penting dalam kegiatan pembelajaran. Jika motivasi belajar siswa tinggi, maka pelajaran juga akan mudah dipahami dan dimengerti, sebaliknya jika motivasi belajar siswa rendah, belajar akan terasa sulit walaupun materi yang dipelajari sangat mudah. Usaha untuk memotivasi siswa dari luar jika dilakukan secara berkelanjutan bisa memacu siswa untuk menciptakan motivasi dari dalam diri siswa.

Permasalahan seperti kurangnya motivasi belajar, aktifitas dalam kelas yang pasif, serta hasil belajar yang kurang memuaskan harus segera mendapatkan solusi yang tepat agar tidak berkelanjutan. Penggunaan metode yang berbeda, model pembelajaran yang menarik, pemanfaatan media pembelajaran serta pemberian motivasi kepada siswa dapat menjadi alternatif pilihan. Solusi yang akan diterapkan adalah pemberian motivasi menggunakan model Attention, Relevance, Confidence, Satisfaction (ARCS), penerapan model Student Teams Achievement Divisions (STAD) dan Numbered Heads Together $(N H T)$.

Motivasi adalah proses psikologis yang dapat menjelaskan perilaku seseorang, perilaku hakikatnya adalah orientasi pada satu tujuan (Uno, 2012: 5). Sebagai upaya meningkatkan pembelajaran di tingkat pendidikan tinggi di Indonesia, Direktorat Jendral Pendidikan Tinggi - Departemen Pendidikan Nasional mengembangkan program PEKERTI (Peningkatan Keterampilan Dasar Teknik Intruksional). Dalam buku Pedoman Penatar PEKERTI-AA (Ditjen Dikti, 2004: 12) diberikan sebuah model pengelolaan motivasi belajar yang dikenal dengan istilah $A R C S$, merupakan akronim dari: Attention (perhatian), Relevance (kesesuaian), Confidence (Kepercayaan Diri), dan Satisfaction (kepuasan) (Gintings, 2008: 101). 
Penerapan ARCS dimaksudkan untuk memacu semangat siswa dalam kegiatan pembelajaran. Menurut Gintings (2008: 101) keempat faktor tersebut merupakan faktor - faktor yang dapat membangkitkan motivasi siswa dalam pembelajaran di kelas. Dalam penelitian yang dilakukan Sulistiani (2006), strategi motivasi model Assurance, Relevance, Interest, Assesment, Satisfaction (ARIAS) yang berorientasi pada pembelajaran kooperatif mendapat respon yang baik. Dalam penelitian ini diharapkan motivasi ARCS juga bisa mendapatkan respon yang baik pula.

STAD merupakan model pembelajaran dengan menggunakan kelompok kecil (Hanafiah \& Suhana, 2012: 44). Menurut Ahmadi, dkk (2011: 64), dalam penerapannya siswa dikelompokkan secara heterogen kemudian siswa yang pandai menjelaskan anggota lain sampai mengerti. Ukuran kelompok yang ideal adalah empat sampai lima orang. Dengan model pembelajaran ini, siswa menjadi aktif karena terjadi interaksi dalam kelompok - kelompok kecil dan bila dilakukan secara berkelanjutan akan berdampak baik bagi siswa untuk meningkatkan aktifitas dalam kelas.

Dalam penelitian yang dilakukan oleh Kurniawan (2004), disimpulkan bahwa model STAD dapat meningkatkan prestasi siswa, sedangkan menurut penelitian Patmiati (2005), model STAD kurang cocok digunakan pada materi himpunan karena belum bisa meningkatkan keaktifan siswa untuk berpartisipasi dalam kegiatan kelompok. Penelitian pada materi yang berbeda diharapkan dapat memberikan dampak yang baik sehingga mampu meningkatkan hasil belajar siswa.

Menurut Ahmadi, dkk (2011: 59), NHT adalah suatu model pembelajaran di mana setiap siswa diberi nomor dan dibuat suatu kelompok kemudian secara acak guru memanggil nomor dari siswa. Dalam model pembelajaran NHT, siswa dituntut selalu siap ketika pembelajaran berlangsung karena guru bisa menunjuk siapa saja di dalam kelas untuk maju presentasi, sehingga siswa akan mempersiapkan dirinya sebelum pembelajaran berlangsung. Hal tersebut dapat menumbuhkan motivasi siswa untuk mempersiapkan diri dengan belajar sebelumnya. Menurut penelitian yang dilakukan oleh Yuanita E. (2005) dan Zumrotussa'adah (2007), dapat disimpulkan bahwa model NHT terbukti efektif untuk meningkatkan hasil belajar siswa.

$A R C S$ akan diterapkan pada model pembelajaran STAD dan model pembelajaran NHT pada kelas berbeda dengan tingkat kemampuan yang sama. Setelah dilakukan 
penerapan terhadap keduanya kemungkinan akan diperoleh hasil yang bervariasi dari segi penerapan pembelajaran, hasil belajar, aktifitas siswa dan guru serta motivasi belajar siswa, jika bukan $S T A D$ yang lebih unggul dan lebih baik maka sebaliknya. Berdasarkan langkah pembelajaran dan hasil penelitian terdahulu, lebih banyak terjadi interaksi antar siswa dalam model STAD sehingga model tersebut lebih berpengaruh terhadap aktifitas siswa. Sedangkan dari nilai hasil belajar, model NHT lebih berpengaruh karena siswa dituntut paham secara individu dalam setiap pertemuan sehingga hasil belajar siswa menjadi baik. Model STAD dan NHT merupakan model pembelajaran berkelompok yang menarik dan menyenangkan.

\section{Rumusan Masalah}

Berdasarkan latar belakang masalah di atas, maka rumusan masalah penelitian adalah:

1. Bagaimana penerapan ARCS pada pembelajaran Matematika menggunakan model STAD dan NHT?

2. Bagaimana aktifitas guru dan aktifitas belajar siswa dalam penerapan ARCS pada pembelajaran Matematika menggunakan model STAD dan NHT?

3. Bagaimana hasil belajar siswa dalam penerapan ARCS pada pembelajaran Matematika menggunakan model STAD dan NHT?

4. Bagaimana motivasi belajar siswa dalam penerapan ARCS pada pembelajaran Matematika menggunakan model STAD dan NHT?

\section{METODE PENELITIAN}

Pendekatan yang akan digunakan dalam penelitian ini nantinya adalah pendekatan kualitatif dan kuantitatif. Penelitian ini melibatkan variabel bebas dan variabel terikat pada waktu bersamaan. Lokasi yang akan dijadikan sebagai tempat untuk melaksanakan penelitian ini adalah di SMP Negeri 3 Ampelgading Malang.

Subjek dalam penelitian ini adalah penerapan ARCS menggunakan model pembelajaran STAD dan NHT untuk melihat aktifitas guru dan aktifitas belajar siswa ketika proses pembelajaran, hasil belajar siswa yang dilihat dari tugas individu dan ulangan harian serta motivasi siswa dalam belajar. Objek dalam penelitian ini adalah seluruh siswa kelas VIII di SMP Negeri 3 Ampelgading Malang. Kelas VIII di sekolah 
tersebut terdiri dari dua kelas yaitu kelas VIII-A dan VIII-B. Pada masing - masing kelas akan diterapkan model pembelajaran yang berbeda dengan materi yang sama.

Data - data yang akan diambil dalam penelitian adalah: 1) Data aktifitas guru dan aktifitas belajar siswa selama kegiatan pembelajaran ketika menerapkan model ARCS dengan menggunakan model pembelajaran STAD dan NHT. Data aktifitas belajar siswa dalam pembelajaran terdiri dari: a) kegiatan visual (visual activities) berupa membaca; b) kegiatan lisan (oral activities) berupa mengajukan pertanyaan, memberi saran, mengemukakan pendapat, diskusi; c) kegiatan mendengarkan (listening activities) berupa mendengarkan penyajian bahan, mendengarkan diskusi kelompok; d) kegiatan menulis (writing activities) berupa membuat rangkuman, mengerjakan tes; 2) Data hasil belajar siswa berupa nilai yang terdiri dari nilai tugas individu pada setiap pertemuan serta nilai ulangan harian di akhir pertemuan; 3) Data tentang motivasi belajar siswa sebelum dan setelah dilaksanakan pembelajaran dengan memberikan motivasi menggunakan model ARCS dengan model pembelajaran STAD dan NHT.

Sumber data yang pertama diperoleh dari hasil observasi aktifitas guru dan aktifitas siswa kelas VIII-A dan VIII-B di SMP Negeri 3 Ampelgading Malang semester ganjil tahun ajaran 2013-2014 selama proses pembelajaran berlangsung. Sumber data yang kedua diperoleh dari nilai tugas individu serta nilai ulangan harian. Sumber data yang ketiga diperoleh dari hasil pengisian angket yang diisi siswa sebelum dan sesudah pelaksanaan eksperimen.

\section{HASIL PENELITIAN}

\section{Penerapan ARCS menggunakan model pembelajaran STAD dan NHT}

Dalam penerapan ARCS menggunakan model STAD dan NHT di kelas VIII-A dan VIII-B selama lima kali pertemuan, satu pertemuan digunakan untuk tes awal, satu pertemuan digunakan untuk ulangan harian dan tiga kali pertemuan digunakan untuk pemberian materi serta melakukan observasi aktifitas guru dan aktifitas belajar siswa selama pembelajaran. Hasil dari tes awal pada pertemuan pertama digunakan sebagai acuan dalam pembentukan kelompok untuk pembelajaran pada pertemuan selanjutnya. Pada pertemuan awal di kedua kelas, kendala yang terlihat adalah siswa terlihat merasa kurang senang dikarenakan pada pertemuan awal setelah perkenalan, langsung 
mengerjakan soal tes awal dan mengisi angket. Namun, hal ini tergolong wajar dan keadaan ini akan diperbaiki pada pertemuan selanjutnya.

Pada pertemuan kedua di kelas VIII-A dan VIII-B, aktifitas guru mengalami kendala yang sama yaitu ketika memberikan contoh kejadian pada dunia nyata yang memiliki keterkaitan pada materi yang akan diajarkan, sehingga guru kurang dapat membuat siswa tertarik dengan materi yang akan diajarkan. Untuk kelas VIII-B kendala aktifitas guru yang lain adalah guru kurang dalam mereview materi pada pertemuan sebelumnya dan guru belum memberikan sanjungan terhadap kelompok yang melakukan diskusi dengan aktif maupun terhadap siswa yang sudah mengikuti pelajaran dengan baik.

Kendala yang sama terjadi di kelas VIII-A dan VIII-B yaitu pada saat siswa harus memberikan saran maupun mengemukakan pendapat. Namun, hal seperti ini tergolong wajar jika terjadi pada pertemuan awal ketika penerapan model baru pada pembelajaran. Kendala yang lain di kelas VIII-A adalah ketika siswa diminta memahami masalah yang diberikan dengan membaca, selain itu siswa juga kurang antusias ketika mendengarkan presentasi. Pada awalnya beberapa siswa tidak puas dengan pembagian kelompok karena ditentukan oleh guru, bukan sesuai keinginan mereka. Namun pada akhirnya siswa dapat menerima dan mengikuti pembelajaran dengan baik. Pada pertemuan ini motivasi belajar siswa belum terlihat dikarenakan masih dalam awal penerapan model pembelajaran baru.

Pada pertemuan ketiga baik di kelas VIII-A maupun VIII-B, aktifitas guru ketika memberikan contoh pada dunia nyata yang berkaitan dengan materi mengalami peningkatan daripada pertemuan sebelumnya, di mana pada pertemuan ketiga ini guru dapat membuat siswa tertarik pada materi yang diajarkan. Di kelas VIII-B guru dapat mereview materi pertemuan sebelumnya dengan baik, selain itu guru juga sudah mulai memberikan sanjungan terhadap kelompok yang melakukan diskusi dengan aktif dan sebelum menutup pelajaran, guru juga memberikan pujian terhadap siswa yang sudah mengikuti pembelajaran dengan aktif dan meminta siswa yang belum berperan aktif untuk dapat aktif pada pertemuan selanjutnya.

Ketika pembelajaran berlangsung di kelas VIII-A dan VIII-B, siswa sudah mulai berani untuk memberikan saran dan mengemukakan pendapat mereka. Sedangkan di 
kelas VIII-A sebagian besar siswa sudah mulai bisa memahami materi yang diberikan dengan mambaca modul yang diberikan oleh guru, siswa juga mulai antusias ketika mendengarkan temannya menyajikan materi di depan kelas. Pada kedua kelas dapat dilihat bahwa ada motivasi pada diri siswa untuk memahami materi dengan membaca dan motivasi untuk berani memberikan saran dan mengemukakan pendapat.

Pada pertemuan keempat di kelas VIII-A dan VIII-B, peneliti selalu berusaha untuk belajar dari kekurangan dan kendala yang terjadi dari setiap pertemuan sehingga aktifitas guru pada pertemuan terakhir ini seluruhnya berada pada kategori sangat baik. Aktifitas siswa di kelas VIII-A pada pertemuan ini hampir sama dengan pertemuan sebelumnya, tidak terjadi banyak peningkatan pada aktifitas siswa, namun siswa terlihat lebih aktif ketika mendengarkan penyajian bahan dan pada saat melakukan diskusi kelompok. Di kelas VIII-A terlihat adanya motivasi siswa untuk memahami materi dengan cara mendengarkan penyajian bahan dan melakukan diskusi dengan maksimal.

Sedangkan di kelas VIII-B siswa mengalami peningkatan aktifitas pada saat memberikan saran dan menegmukakan pendapat, sehingga terlihat semakin tinggi motivasi siswa untuk berpartisipasi dalam memberikan saran dan berpendapat, hal ini terlihat dari semakin banyaknya siswa yang berani mencoba memberikan saran dan memberikan pendapat.

Pada pertemuan kelima baik di kelas VIII-A maupun VIII-B, setelah seluruh siswa selesai mengerjakan ulangan harian dan mengisi angket, guru mengajak siswa untuk koreksi ulangan harian mereka, sehingga akan langsung diketahui tiga siswa terbaik berdasarkan nilai ulangan harian dan kelompok terbaik berdasarkan kriteria penilaian yang sudah ditetapkan.

Aktifitas Guru dan Aktifitas Belajar Siswa dalam Penerapan ARCS menggunakan model pembelajaran STAD dan NHT

Di kelas VIII-A rata - rata aktifitas guru pada pertemuan kedua mencapai 86,66\% dengan kategori baik, pada pertemuan ketiga mencapai 94,60\% dengan kategori sangat baik dan pada pertemuan keempat mencapai 100\% dengan kategori sangat baik. Pada pertemuan kedua tanggal 30 Oktober 2013, dalam kegiatan awal untuk indikator ketiga, guru mendapatkan nilai yang rendah, hal ini dikarenakan guru kurang dapat menarik 
perhatian siswa pada pembelajaran dengan contoh yang diberikan sedangkan untuk indikator lain, guru mendapat skor yang baik. Pada pertemuan ketiga, kendala yang terjadi pada pertemuan kedua sudah dapat diperbaiki, yaitu pada kegiatan awal indikator ketiga di mana guru sudah dapat menarik perhatian siswa dengan contoh yang diberikan. Di kelas VIII-A aktifitas guru selalu mengalami peningkatan untuk setiap pertemuan.

Sedangkan di kelas VIII-B rata - rata aktifitas guru pada pertemuan kedua mencapai $81,26 \%$ dengan kategori baik, pada pertemuan ketiga mencapai 95,79\% dengan kategori sangat baik dan pada pertemuan keempat mencapai 100\% dengan kategori sangat baik. Ketika pertemuan kedua, guru kurang dapat memberikan contoh yang dapat menarik perhatian siswa terhadap pembelajaran sehingga guru mendapatkan skor yang rendah, begitu juga pada saat mereview materi dan memberikan sanjungan serta pujian terhadap siswa ketika pembelajaran. Namun, pada pertemuan ketiga ini, kendala yang terjadi pada pertemuan kedua bisa diperbaiki oleh guru sehingga aktifitas guru pada pertemuan ini mengalami peningkatan dari pertemuan sebelumnya.

Pada pertemuan kedua aktifitas guru di kelas VIII-A mencapai 86,66\% sedangkan di kelas VIII-B mencapai $81,26 \%$ sehingga rata - rata aktifitas guru di kelas VIII-A lebih tinggi daripada di kelas VIII-B. Pada pertemuan ketiga aktifitas guru di kelas VIIIA mencapai $94,60 \%$ sedangkan di kelas VIII-B mencapai $95,79 \%$ sehingga rata - rata aktifitas guru di kelas VIII-B lebih tinggi daripada di kelas VIII-A. Pada pertemuan keempat aktifitas guru di kelas VIII-A dan VIII-B mencapai skor yang sama yaitu 100\%. Secara keseluruhan aktifitas guru di kelas VIII-A dan VIII-B selalu mengalami peningkatan.

Pada pembahasan ini akan dijelaskan tentang aktifitas belajar siswa di kelas VIIIA dan kelas VIII-B selama tiga kali pertemuan dalam tiga minggu serta bagaimana perkembangan aktifitas siswa di setiap pertemuan tersebut. Di kelas VIII-A aktifitas siswa dalam memahami masalah yang diberikan dengan membaca mengalami peningkatan dari pertemuan kedua ke pertemuan ketiga, dan berada pada kondisi yang sama pada pertemuan keempat sehingga berada pada kategori baik. Sedangkan di kelas VIII-B aktifitas siswa mengalami peningkatan pada setiap pertemuan dan berada pada 
kategori baik. Pada indikator ini, siswa kelas VIII-B lebih bisa memahami materi dengan membaca daripada kelas VIII-A.

Di kelas VIII-A aktifitas siswa dalam mengajukan pertanyaan mengalami peningkatan dari pertemuan kedua ke pertemuan ketiga, dan berada pada kondisi yang sama pada pertemuan ketiga sehingga berada pada kategori baik. Sedangkan di kelas VIII-B aktifitas siswa mengalami peningkatan pada setiap pertemuan sehingga berada pada kategori baik. Hal ini menunjukkan bahwa baik siswa kelas VIII-A maupun siswa kelas VIII-B sama - sama memberikan kesan baik ketika mengajukan pertanyaan, namun kelas VIII-B terlihat lebih unggul dikarenakan ada peningkatan di setiap pertemuan.

Di kelas VIII-A aktifitas siswa dalam memberi saran dan mengemukakan pendapat mengalami peningkatan dari pertemuan kedua ke pertemuan ketiga, dan berada pada kondisi yang sama pada pertemuan keempat sehingga berada pada kategori baik. Sedangkan di kelas VIII-B aktifitas siswa mengalami peningkatan pada setiap pertemuan sehingga berada pada kategori baik. Pada saat mengajukan pertanyaan, memberi saran dan mengemukakan pendapat, kedua aktifitas tersebut memiliki skor yang sama, hal ini disebabkan karena adanya kesamaan dan keterkaitan dari segi keberanian siswa.

Di kelas VIII-A aktifitas siswa ketika melaksanakan diskusi pada pertemuan kedua, ketiga dan keempat skor yang diperoleh adalah 100\% sehingga berada pada kategori sangat baik. Sedangkan di kelas VIII-B aktifitas siswa pada pertemuan kedua, ketiga dan keempat skor yang diperoleh adalah $100 \%$ sehingga berada pada kategori sangat baik. Dapat dilihat bahwa skor yang diperoleh siswa kelas VIII-A dan VIII-B pada setiap pertemuan adalah sama dan selalu mendapatkan skor sempurna yaitu $100 \%$. Hal ini membuktikan bahwa siswa pada kedua kelas menyukai pembelajaran dengan cara diskusi kelompok sehingga cara ini bisa menjadi alternatif ketika melakukan pembelajaran selanjutnya.

Di kelas VIII-A aktifitas siswa ketika mendengarkan penyajian bahan selalu mengalami peningkatan pada setiap pertemuan sehingga berada pada kategori sangat baik. Sedangkan di kelas VIII-B aktifitas siswa pada pertemuan kedua, ketiga dan keempat skor yang diperoleh adalah $100 \%$ sehingga berada pada kategori sangat baik. 
Dapat dilihat bahwa siswa di kelas VIII-A memiliki keinginan untuk mendengarkan penyajian bahan materi yang dijelaskan di kelas, terbukti dengan adanya peningkatan skor pada aktifitas di setiap pertemuannya.

Sedangkan untuk kelas VIII-B selalu mendapatkan skor sempurna yaitu 100\%, ini membuktikan bahwa dari awal pembelajaran, siswa menaruh perhatian penuh dalam penyajian materi. Perbedaan aktifitas ini disebabkan karena pada kelas VIII-A penyajian bahan berupa materi sedangkan pada kelas VIII-B penyajian bahan langsung pada contoh soal. Siswa cenderung lebih cepat memahami materi ketika sudah masuk pada contoh soal karena siswa tidak hanya memikirkan di angan - angan tetapi langsung mengerjakan pada selembar kertas.

Di kelas VIII-A aktifitas siswa ketika mendengarkan diskusi kelompok berada pada kondisi yang sama pada pertemuan kedua dan pertemuan ketiga dan terdapat peningkatan dari pertemuan ketiga ke pertemuan keempat sehingga berada pada kategori sangat baik. Sedangkan di kelas VIII-B aktifitas siswa pada setiap pertemuan skor yang diperoleh adalah $100 \%$ sehingga berada pada kategori sangat baik. Pada kelas VIII-A pada pertemuan kedua dan ketiga siswa terlihat berada pada katagori sama yang menunjukkan bahwa siswa tidak memiliki keinginan untuk mendengarkan diskusi kelompok lebih baik dari pertemuan sebelumnya. Namun pada pertemuan ketiga kondisi ini terlihat membaik dengan adanya peningkatan pada skor aktifitas belajar siswa. Sedangkan untuk kelas VIII-B selalu mendapatkan skor sempurna yaitu $100 \%$, ini membuktikan bahwa dari awal pembelajaran, siswa menaruh perhatian penuh dalam mendengarkan diskusi kelompok yang berlangsung di kelas.

Di kelas VIII-A aktifitas siswa ketika membuat rangkuman memperoleh hasil yang tetap pada setiap pertemuan sehingga berada pada kategori baik. Sedangkan di kelas VIII-B aktifitas siswa mengalami peningkatan pada setiap pertemuan sehingga berada pada kategori sangat baik. Pada kelas VIII-A siswa selalu berada pada kondisi yang sama di setiap pertemuan dan tidak mengalami peningkatan, hal ini disebabkan karena keinginan siswa untuk membuat rangkuman terlihat sedikit kurang. Kondisi yang terjadi adalah apabila hari ini siswa membuat rangkuman, belum tentu pada pertemuan selanjutnya siswa tersebut juga membuat rangkuman. Sedangkan di kelas 
VIII-B terlihat adanya keinginan siswa untuk membuat rangkuman, hal ini terbukti dari skor aktifitas siswa yang terus meningkat pada setiap pertemuan.

Di kelas VIII-A dan VIII-B aktifitas siswa ketika mengerjakan tes pada pertemuan kedua, ketiga dan keempat skor yang diperoleh adalah 100\% sehingga berada pada kategori baik. Pada writing activities indikator kedua, seluruh siswa memiliki antusias yang bagus dalam mengerjakan tes atau soal yang diberikan, sehingga baik kelas VIII-A maupun VIII-B selalu memiliki skor yang sempurna yaitu 100\% dari pertemuan kedua hingga pertemuan keempat.

Setelah dilakukan observasi aktifitas belajar siswa di kelas VIII-A dan VIII-B di SMP Negeri 3 Ampelgading Malang selama tiga kali pertemuan yang diukur melalui 4 jenis aktifitas dengan 8 indikator yang diamati dapat ditarik kesimpulan sebagai berikut: 1) di kelas VIII-A rata - rata aktifitas siswa pada pertemuan kedua sebesar $76,61 \%$ dengan kategori baik sedangkan di kelas VIII-B sebesar 87,31\% dengan kategori baik; 2) di kelas VIII-A rata - rata pada pertemuan ketiga sebesar $81,07 \%$ dengan kategori baik sedangkan di kelas VIII-B sebesar 90,53\% dengan kategori sangat baik; 3) di kelas VIII-A rata - rata pada pertemuan keempat sebesar $86,61 \%$ dengan kategori baik sedangkan di kelas VIII-B sebesar 93,37\% dengan kategori sangat baik. Selama tiga kali pertemuan, aktifitas siswa kelas VIII-B selalu lebih baik daripada aktifitas kelas VIII-A. Secara keseluruhan aktifitas siswa di kelas VIII-A selalu mengalami peningkatan di setiap pertemuannya dan selalu berada pada kategori baik. Sedangkan aktifitas siswa di kelas VIII-B selalu mengalami peningkatan di setiap pertemuannya, di mana pada pertemuan kedua berada pada kategori baik dan berada pada kategori sangat baik pada pertemuan lainnya.

Hasil Belajar Siswa dalam Penerapan ARCS menggunakan model pembelajaran STAD dan NHT

Pada pertemuan kedua nilai rata - rata kelas VIII-A mencapai 68,08 sedangkan VIII-B mencapai 68,09. Pada pertemuan ketiga nilai rata - rata kelas VIII-A mencapai 68,88 sedangkan kelas VIII-B mencapai 79,54. Pada pertemuan keempat nilai rata - rata kelas VIII-A mencapai 81,83 sedangkan kelas VIII-B mencapai 84,30. Di kelas VIII-A dari pertemuan kedua ke pertemuan ketiga, kenaikan nilai rata - rata hanya 0,80 dari 
nilai sebelumnya sedangkan di kelas VIII-B adalah 11,45 dari nilai sebelumnya. Sedangkan dari pertemuan ketiga ke pertemuan keempat, kenaikan nilai kelas VIII-A cukup besar yaitu 12,95 dari nilai sebelumnya, sedangkan di kelas VIII-B kenaikan nilai adalah 4, 76 dari nilai sebelumnya. Secara keseluruhan siswa pada kelas VIII-A dan VIII-B selalu mengalami peningkatan setiap pertemuan.

Peningkatan skor siswa selama pembelajaran berlangsung dilihat dari nilai tugas individu. Nilai individu akan berpengaruh terhadap nilai kelompok dan nantinya nilai tersebut digunakan untuk menentukan tiga kelompok terbaik. Peningkatan skor dari pertemuan kedua ke pertemuan ketiga akan dijumlahkan dengan peningkatan skor dari pertemuan ketiga ke pertemuan keempat yang akan dibagi dua untuk mendapatkan nilai kelompok selama pembelajaran tersebut.

Di kelas VIII-A tim hebat pertama mendapat nilai kelompok 23,35 dan tim hebat kedua mendapat nilai kelompok 22,10 serta tim hebat ketiga mendapat nilai kelompok 21,66. Sedangkan di kelas VIII-B tim hebat pertama mendapat nilai kelompok 24 dan tim hebat kedua mendapat nilai kelompok 22,08 serta tim hebat ketiga mendapat nilai kelompok 21,66. Ketuntasan hasil belajar siswa dilihat berdasarkan nilai ulangan harian. Di kelas VIII-A dengan jumlah 35 siswa, 30 siswa dinyatakan tuntas secara individu dan 5 orang siswa dinyatakan tidak tuntas. Terdapat $85,71 \%$ dari jumlah siswa di kelas yang sudah mencapai nilai $\geq 70$ sehingga hasil belajar siswa kelas VIII-A dapat dinyatakan tuntas secara klasikal. Sedangkan di kelas VIII-B dengan jumlah 33 siswa, 25 siswa dinyatakan tuntas secara individu dan 8 orang siswa dinyatakan tidak tuntas. Hanya terdapat $75,76 \%$ dari jumlah siswa di kelas yang mencapai nilai $\geq 70$ sehingga hasil belajar siswa kelas VIII-B dinyatakan belum tuntas secara klasikal.

Berdasarkan analisis data yang menggunakan Independet Sample t-Test, 35 siswa kelas VIII-A untuk kelompok 1 dengan perlakuan menggunakan model ARCS dan model STAD dengan nilai rata - rata kemampuan akhir 75,66 dan 33 siswa kelas VIII-B untuk kelompok 2 dengan perlakuan menggunakan model ARCS dan model NHT dengan nilai rata - rata kemampuan akhir 77,51. Pada lampiran 9, terlihat bahwa nilai probabilitas $0,057>0,05$. Berdasarkan syarat probabilitas yaitu jika probabilitas $>0,05$ $H_{0}$ diterima dan jika probabilitas $<0,05 H_{0}$ ditolak, maka kini berarti bahwa $H_{0}$ diterima dan berarti tidak ada perbedaan antara hasil belajar siswa yang mendapat perlakuan 
menggunakan model ARCS dan STAD dengan siswa yang mendapat perlakuan menggunakan model ARCS dan NHT, namun hasil belajar kelas VIII-B lebih baik daripada kelas VIII-A.

Motivasi Belajar Siswa dalam Penerapan ARCS menggunakan model pembelajaran STAD dan NHT

Total skor angket diambil dari skor setiap pernyataan angket yang telah diisi oleh siswa kelas VIII-A dan VIII-B pada pertemuan pertama dan kelima. Setelah didapatkan total skor akan dikategorikan sesuai ketentuan sebelumnya. Sebelum penerapan model ARCS, model STAD dan model NHT, motivasi belajar siswa di kelas VIII-A dan VIII-B masih ada yang berada pada kategori kurang bahkan ada beberapa yang berada pada kategori sangat kurang, sebagian besar masih pada kategori cukup dan hanya sebagian kecil pada kategori baik untuk motivasi belajar siswa. Dengan menerapkan model $A R C S$, model STAD dan model NHT diharapkan dapat meningkatkan motivasi siswa dalam belajar.

Setelah penerapan model ARCS, model STAD dan model NHT tidak ada siswa yang berada pada kategori sangat kurang maupun kurang untuk motivasi belajar mereka, namun masih ada beberapa siswa yang berada pada kategori cukup. Sebagian besar dari siswa sudah memiliki motivasi belajar yang baik, bahkan ada beberapa yang memiliki motivasi belajar yang sangat baik. Dengan demikian dapat disimpulkan bahwa penerapan model ARCS, model STAD dan model NHT dapat meningkatkan motivasi belajar siswa kelas VIII-A dan VIII-B.

Berdasarkan analisis data yang menggunakan SPSS melalui Independet Sample t-Test, 35 siswa kelas VIII-A untuk kelompok 1 dengan perlakuan menggunakan model $A R C S$ dan model STAD dengan nilai rata - rata 82,26 dan 33 siswa kelas VIII-B untuk kelompok 2 dengan perlakuan menggunakan model ARCS dan model NHT dengan nilai rata - rata 75,48. Pada lampiran 10, terlihat bahwa probabilitas 0,093>0,05. Berdasarkan syarat probabilitas yaitu jika probabilitas $>0,05 H_{0}$ diterima dan jika probabilitas $<0,05 H_{0}$ ditolak, maka kini berarti bahwa $H_{0}$ diterima dan berarti tidak ada perbedaan antara motivasi belajar siswa yang mendapat perlakuan menggunakan model $A R C S$ dan STAD dengan siswa yang mendapat perlakuan menggunakan model ARCS 
dan NHT, namun motivasi belajar siswa kelas VIII-A lebih baik daripada siswa kelas VIII-B.

\section{Simpulan}

Berdasarkan hasil penelitian yang telah dilaksanakan dapat disimpulkan bahwa:

1. Pada pembelajaran dengan penerapan ARCS pada pembelajaran matematika menggunakan model STAD dan NHT di SMP Negeri 3 Ampelgading Malang telah mencapai tujuan yang diinginkan, yaitu dapat meningkatkan hasil belajar siswa secara klasikal sesuai dengan KKM dari sekolah. Kegiatan belajar mengajar yang dilakukan selama 5 kali pertemuan pada kelas VIII-A dan kelas VIII-B sesuai dengan yang telah direncanakan di dalam RPP. Terdapat sedikit kendala pada awal pembelajaran dikarenakan kondisi siswa yang masih sulit menyesuaikan diri dengan guru maupun sebaliknya. Namun, hal tersebut dapat diatasi dan dapat diperbaiki pada pertemuan berikutnya sehingga hasil belajar siswa lebih aktif dan efektif yang ditunjukkan dengan adanya peningkatan hasil belajar.

2. Aktifitas guru di kelas VIII-A dan VIII-B selalu mengalami peningkatan pada setiap pertemuan. Pada pertemuan kedua aktifitas guru di kelas VIII-A lebih baik daripada di kelas VIII-B dan pada pertemuan ketiga aktifitas guru di kelas VIII-B lebih baik daripada di kelas VIII-A sedangkan pada pertemuan keempat aktifitas guru pada kedua kelas mencapai skor yang sama. Aktifitas belajar siswa di kelas VIII-A dan VIII-B juga selalu mengalami peningkatan pada setiap pertemuan. Namun untuk aktifitas siswa di kelas VIII-B selalu lebih baik daripada kelas VIIIA pada setiap pertemuan. Secara keseluruhan, aktifitas guru dan aktifitas siswa selalu mengalami peningkatan di setiap pertemuan. Hal ini menunjukkan bahwa model ARCS, model STAD dan model NHT merupakan model pembelajaran yang cocok untuk diterapkan di SMP Negeri 3 Ampelgading Malang.

3. Hasil belajar siswa kelas VIII-A dan VIII-B yang diajar menggunakan dua model pembelajaran yang berbeda, dapat dilihat bahwa terdapat perbedaan pada hasil belajar. Perbedaan hasil belajar tersebut telah dijelaskan pada pembahasan penelitian pada bab sebelumnya yaitu perolehan rata - rata hasil belajar untuk kelas VIII-A yang diikuti 35 siswa dengan kemampuan akhir sebesar 75,66 dan 
kelas VIII-B yang diikuti 33 siswa dengan kemampuan akhir sebesar 77,51. Berdasarkan uji statistik menggunakan Independent Sample t-Test, terbukti tidak ada perbedaan hasil belajar antara siswa kelas VIII-A yang diajar menggunakan model ARCS dan STAD dengan siswa kelas VIII-B yang diajar menggunakan model ARCS dan NHT.

4. Motivasi belajar siswa kelas VIII-A dan VIII-B yang diajar menggunakan dua model pembelajaran yang berbeda menyebabkan adanya perbedaan motivasi belajar siswa. Perbedaan motivasi belajar tersebut telah dijelaskan pada pembahasan penelitian pada bab sebelumnya yaitu perolehan rata - rata skor motivasi belajar untuk kelas VIII-A yang diikuti 35 siswa sebesar 82,26 dan kelas VIII-B yang diikuti 33 siswa sebesar 75,48. Berdasarkan uji statistik menggunakan Independent Sample t-Test, terbukti tidak ada perbedaan motivasi belajar antara siswa kelas VIII-A yang diajar menggunakan model ARCS dan $S T A D$ dengan siswa kelas VIII-B yang diajar menggunakan model ARCS dan NHT.

\section{DAFTAR PUSTAKA}

Ahmadi, Khoiru. dkk. (2011). Strategi Pembelajaran Sekolah Terpadu "Pengaruhnya Terhadap Konsep Pembelajaran Sekolah Swasta Dan Negeri". Jakarta: PT. Prestasi Pustakaraya.

Dimyati dan Mudjiono. (2009). Belajar dan Pembelajaran. Jakarta: PT. Rineka Cipta.

Gintings, Abdorrakhman. (2008). Esensi Praktis Belajar dan Pembelajaran. Bandung: Humaniora.

Hanafiah, Nanang. dkk. (2012). Konsep Strategi Pembelajaran. Bandung: PT. Refika Aditama.

Uno, Hamzah. (2012). Teori Motivasi \& Pengukurannya. Jakarta: PT. Bumi Aksara. 